Review

\title{
Sustainability and Resilience in Smart City Planning: A Review
}

\author{
Leonardo Juan Ramirez Lopez *(1) and Angela Ivette Grijalba Castro
}

check for

updates

Citation: Ramirez Lopez, L.J.; Grijalba Castro, A.I. Sustainability and Resilience in Smart City Planning: A Review. Sustainability 2021, 13, 181. https://dx.doi.org/ $10.3390 /$ su13010181

Received: 17 November 2020 Accepted: 23 December 2020 Published: 27 December 2020

Publisher's Note: MDPI stays neutral with regard to jurisdictional claims in published maps and institutional affiliations.

Copyright: () 2020 by the authors. Licensee MDPI, Basel, Switzerland. This article is an open access article distributed under the terms and conditions of the Creative Commons Attribution (CC BY) license (https: / / creativecommons.org/ licenses/by/4.0/).
Department of Engineering, Universidad Militar Nueva Granada, Bogotá 110111481, Colombia; u7700127@unimilitar.edu.co

* Correspondence: leonardo.ramirez@unimilitar.edu.co; Tel.: +57-31149-05014

\begin{abstract}
Urban planning is recognized as an interaction between the state and society, which aims to articulate public policies in the territory, facilitating their administration in favor of greater development and well-being of society. However, this interaction becomes complex because consumption demands increase, and the carrying capacity of the urban ecosystem to supply them is exceeded, hindering its sustainable functionality. With this overview, it becomes relevant to study urban planning from a sustainable environmental planning perspective, based on four topics: urban planning, sustainability, resilience, and smart cities, which are developed throughout the document by means of a chronological study. A bibliometric study was used through a Preferred Reporting Items for Systematic Reviews and Meta-Analyses (PRISMA) adjustment to 87 articles, supported by VOSviewer ${ }^{\circledR}$, which allowed for the construction and visualization of the co-occurrence networks of key words extracted from the selected articles. Likewise, 16 documents more were used for the co-occurrence analysis. The main result is to consider cities with a complex systems approach that works like a gear; the relationship between inter-urban and intra-urban processes is the key factor that allows for an understanding of their synchronization; therefore, deepening of each of these topics is crucial to the ideal of a territorial administration involving time scales and adaptive cycles, allowing for the provision of new tools for concepts such as carrying capacity and the measurement of the ecological footprint.
\end{abstract}

Keywords: planning; resilience; territory; smart city; sustainability

\section{Introduction}

One of the great challenges of the 21st century is being able to find an opportunity for smart environmental planning, understanding the complexity it may represent and approaching it from four aspects - urban planning, sustainability, resilience, and smart cities - to then overcome the challenges related to growing urban densification and the deficit in the supply of basic elements, a scenario that leads us to generate the following question: Does smart growth and smart planning require clear and applied concepts (knowledge) of sustainability and resilience?

\subsection{Urban Planning}

Urban planning is understood as a process of interaction between the government and society: This relationship aims to articulate public policies and their implementation in the territory with local, regional, and country priorities in general, facilitating the administration in favor of greater development and well-being of society [1].

In Colombia, an example of the traditional urban planning instruments includes development plans and territorial planning programs-TPP. Given that they have been deficient, managed under a totalizing approach, said plans promote the destruction of valuable natural resources in the peripheries as well as urban expansion [2]. The latter has occurred with a rapid and disorderly trend, drastically reducing rural areas, and with the potential for agricultural use $[3,4]$. A very similar situation is seen in Venezuela and 
Mexico, where the traditional outline of totaling urban planning is maintained, expanding to the outskirts, ignoring the regulations for land control and use [2,3].

On the other hand, well-thought-out cities are decisive in the solution of sustainable urban planning because they are the most efficient way of living, tending to the optimization of resources and a lower environmental impact per area $[5,6]$. Thus, current urban planning must consider environmental and socioeconomic variables associated with population densification in a combined and symbiotic way [7], allowing a model of territory to be built that favors strategic decision-making based on sustainability and that is applicable to other urban ecosystems [8].

Nevertheless, urban planning has faced the imbalances caused by urban expansion, overexploitation, and the Western consumer society; between 1900 and 2000, the number of inhabitants in the world increased by approximately 220 million [9]. This is how the importance of deepening urban flows that include the cost of economic agents and the rate of depletion of natural resources, guaranteeing an inventory of the latter so as not to use them beyond their regeneration capacity, takes shape [10,11], managing to generate indicators for the analysis of ecosystem urban planning that allows us to capture an approximate panorama of the territory [3,12].

This leads to the need to change obsolete urban and regional planning models for innovative smart and sustainable models, where a special analysis of the transformation of the peripheries is carried out in tune with environmental variables that minimize environmental deterioration, as well as the risk elements generated in an ecosystem, forcing the recognition and understanding of natural systems under sustainability and resilience criteria that lead to smart city planning criteria.

\subsection{Sustainability}

Cuberos perceives the concept of sustainable planning from the understanding of urban ecological systems and from environmental management, seeking to improve the quality of life of its beneficiaries [2], with the ecological footprint being an instrument to analyze consumption and lifestyles; however, the results of this do not guarantee effective decision-making by the organization interested, oriented towards sustainability [13-15]. In addition to this, the concept is perfected under the criteria that correspond to the principle of habitability (from its environmental dimension), physical well-being (that guarantees safety and comfort), and the social welfare criterion (that pursues the formation of senses of appropriation and belonging, and universal access to urban services) [16]. It is clearly specified that sustainability should not revolve around a principle of economic growth and territorial expansion, but rather a sustainable development approach in search of the balance of ecosystems [17]. The International Organization for Standardization (ISO) 37101:2016 standard outlines and evaluates sustainability under an economic, social, and environmental context in a community, promoting the development of a multi-stakeholder process $[18,19]$.

The transformation process that allows for levels of production and sustainability to be obtained may be approached from the urban ecology perspective, focusing on the interaction between urban and ecological systems and converging on the concept of urban ecosystems, which are understood as the spatial symbiosis between the natural and spatial [20], under the premise that systems must remain at equilibrium and need a permanent flow of energy, matter, and information, manifested through a complex and systemic holistic character [21], thus creating an interest in developing urban interventions from a comprehensive perspective, which takes into account the sustainable provision of ecosystem services [22].

\subsection{Resilience}

The ISO 37123:2019 standard takes the concept of a "resilient city, able to handle all the challenges of a changing world", counting on a level of preparation for extreme events, as well as its capacity to respond and rebuild in the face of creating innovative 
initiatives [11,23,24]. For some academics, the concept of resilience in sustainable urban planning demands clarification through theoretical and practical analysis in order to implement urban public policies. In the same vein, an approach of the concept towards adaptation to climate change also emphasizes the new design and planning challenges, which must generate paradigm breaks [25].

From the perspective of an urban ecosystem as a complex system that is composed of three stages (change, adaptation, and transformation), there is another analysis that suggests how ecosystem transformations can be expected or unexpected and their tendency to return to their essential functions [26,27]. It is necessary to consider that this adaptive cycle does not occur in a short-term period, because although initially the environment enters a moment of catharsis, its response capacity occurs in the long term [28]. More recently, the elements of resurgence and internal transformation that help to situate the debate in the most current terms of evolutionary resilience are highlighted [29].

For this reason, it becomes necessary to take advantage of the networking of this complex system to reorganize the structures and available resources [30,31], and to integrate environmental services into the assessment [32-34].

The resilience analysis lacks assessment tools for the decision-makers in the government bodies that allow for the establishment of an adaptation capacity of a complex system that evolves over time and is based on the relationship between the components of the internal system, addressing it as the analysis of a process. In addition, increasing a city's resilience makes it more sustainable, but increasing a city's sustainability does not necessarily make it more resilient, making evident that this type of public policy is mainly aimed at the evaluation of the regulations, but is not aimed at actions and results; therefore, the analysis of urban processes in stages becomes important to link the efficacy of their responses hand in hand with smart cities [21,35].

\subsection{Smart Cities}

The smart city concept is established as those "cities with an intelligent economic, institutional, social and physical infrastructure, which ensure the centralization of their citizens in a sustainable environment", this being a great challenge to achieve [36,37].

Thus, ISO 37122:2019 "Sustainable Cities and Communities-Indicators for smart cities" establishes a series of integrated and interconnected strategies and systems to provide better services and increase quality of life [38-40], ensuring equal opportunities for all, protecting the environment, and including some development factors [41-43] and generating a great capacity for learning, innovation, and creativity alongside institutionalism, leading it towards an inclusive model $[38,44]$. This means placing the citizen at the center, giving them a role that supports technological development through a sustainable and participatory system, strengthening the collective intelligence about information and communication technologies (ICT) [38,45], and using governance to project a vision of the future with an intelligent combination of endowments and activities of independent and conscious citizens [46].

On the other hand, among the most outstanding considerations of a smart city in the measure of the integrated use of ICT are internet networks (IP), mobile, the cloud, big data, and the Internet of Things (IoT). This last one promotes the transition towards the smart city in a practical way, because it is applicable in small sectors of a population and enhances the areas of development of these [47].

\section{Materials and Methods}

To delve into the topics raised above, a systematic review of literature available in multidisciplinary scientific journals was carried out. The objective of the review focused on the availability of information related to the conceptualization and the different approaches used for territorial administration under a sustainability approach. We then evaluated the progress made by different researchers around the world, classifying and studying peer-reviewed journal articles. Figure 1 shows the evaluation process carried out in four 
phases:

a. A compilation of the information was carried out in several scientific database search engines (Scopus, Web of Science, and Google Scholar) through the use of Boolean operators "AND" and "OR"; documents whose titles or abstracts contained the words listed below were included, from 2010 to 2020:

(TITLE-ABS-KEY ("Urban* Planning*") OR

TITLE-ABS-KEY ("urban ecosystems") AND

TITLE-ABS-KEY ("sustainability") OR

TITLE-ABS-KEY ("urban resilience") OR

TITLE-ABS-KEY ("smart cities")

The inclusion criteria used were open data investigation limited to the following areas of interest: social sciences, engineering, computer science, urbanism, and agricultural sciences. Articles in the following languages were considered: English, Portuguese, and Spanish.

b. Identification of duplicates was required, as some articles appeared in more than one database.

c. For the quality evaluation, the Preferred Reporting Items for Systematic Reviews and Meta-Analyses (PRISMA) tool was used for each article, providing an objective comparison between the articles and their classification.

d. Finally, grouping was applied through the use of VOSviewer $₫$, applying to the latter a viewer of keywords where they were correlated, giving a weight to each word according to the number of times it was mentioned in the selected information.

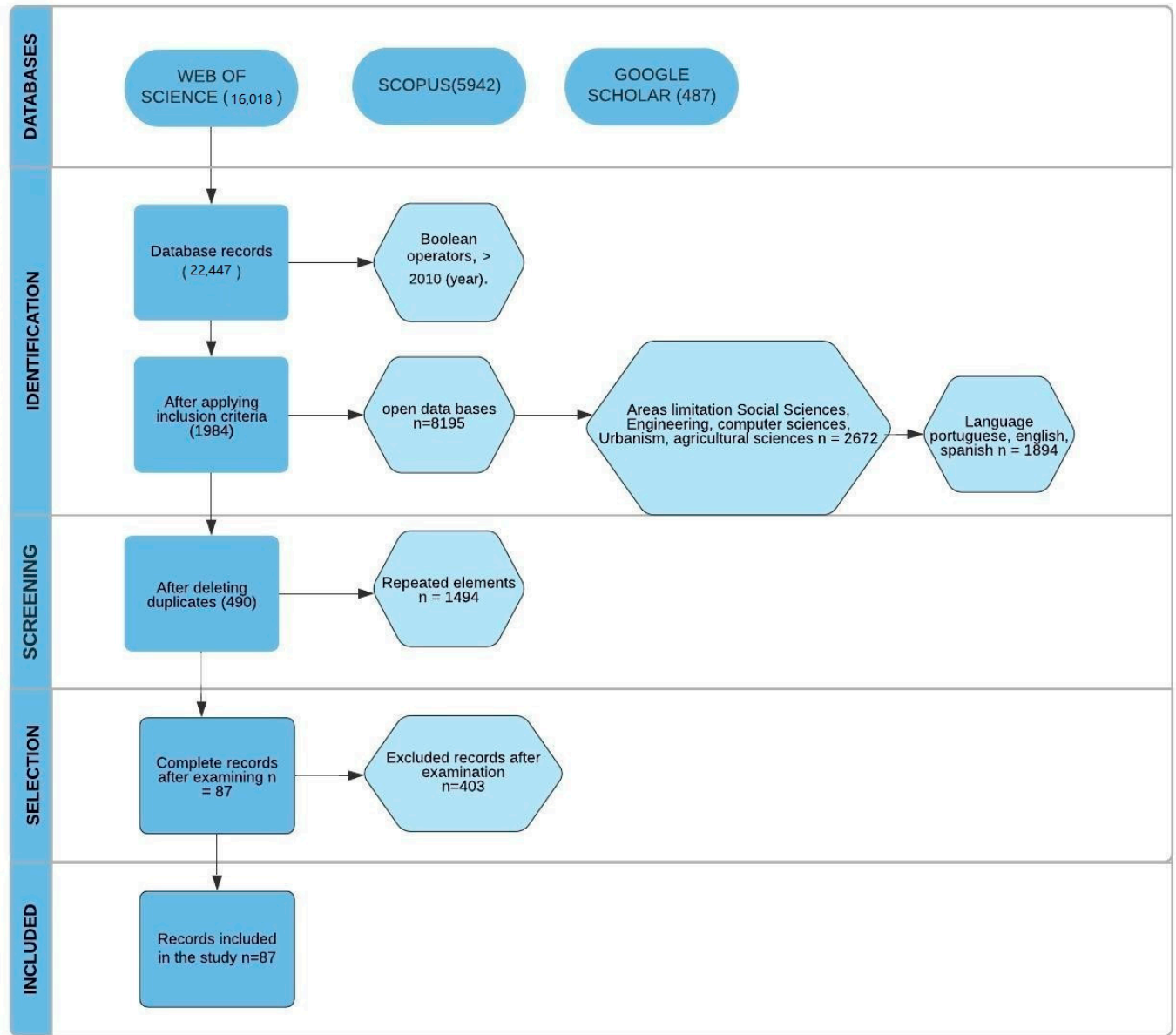

Figure 1. Methodology of analysis. 
With this approach, the common points and the differences between urban planning, sustainability, resilience, and smart cities were determined to identify key elements that could be used for their conceptualization. To that end, 16 documents were included, among reports, guides, conferences of agencies such as United Nations (UN), United Nations Environment Programme (UNEP), the Center for the Implementation of Public Policies Promoting Equity and Growth (CIPPEC, by the Spanish acronym), and ISO standards, for a total of 103 documents.

\section{Co-Occurrence Analysis}

To better understand the approach of the four topics, we used the method stated above in 103 articles from 1970 to 2020 that included the Boolean formulation, building networks of co-occurrence of keywords. Figure 2 shows the dominant position using the VOSviewer $^{\circledR}$ tool: more than 22 terms out of 122 in total linked in these studied topics (urban planning, sustainability, resilience, and smart cities).

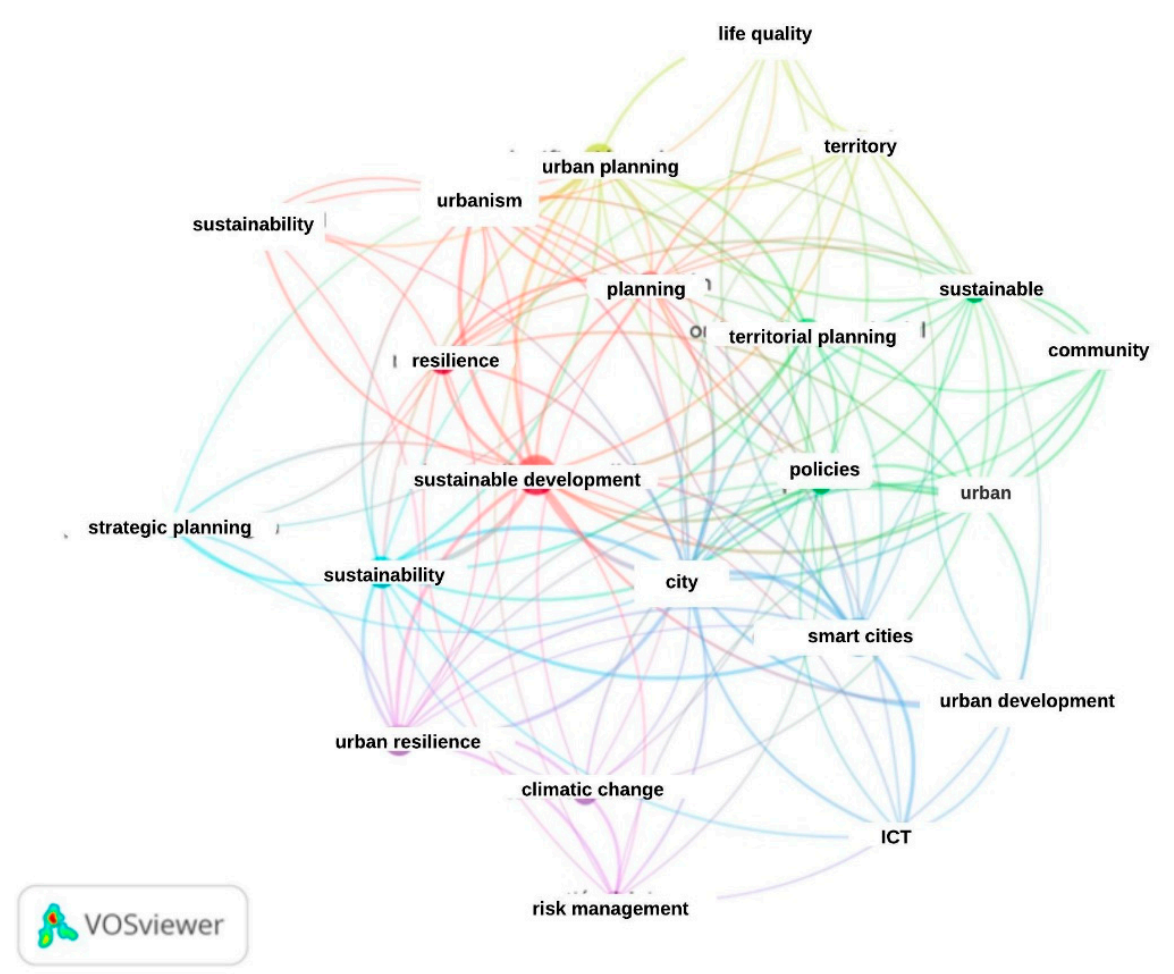

Figure 2. Co-occurrence analysis of terms.

Figure 2 shows the constitution of 6 clusters, which showed the following behavior: red, where the term "sustainable development" was predominant, with 24 occurrences; yellow, with "urban planning" as the dominant term, with 16 occurrences; green, for "territorial planning" with 10 occurrences; blue, for the term "smart city" with 21 occurrences; violet, with "urban resilience" being predominant with 15 occurrences; and finally, turquoise blue for "sustainability" with 15 occurrences. The domain of the approach of the formulation was confirmed: city, smart city, sustainable development, resilience, urbanism, urban planning, and sustainability.

In the discourse of urban planning-as observed in Figure 2-the words that obtained higher weight were "urbanism," "sustainable development," "city," and "smart city," and we perceived the needs of academics in general to articulate the three classic dimensions: environmental, economic, and social supported by technology, with a behavior very similar to the cluster linked to "sustainability" (turquoise blue), "urban resilience," and "smart city." 
Additionally, it could be determined that the ideal path for the construction of territory can be carried out only through sustainable development without giving sufficient importance to the variables of resilience, urban resilience, and risk management, making it impossible to achieve the ultimate objective in urban planning, which is improving quality of life. That is, a city is considered as something static, putting aside its conception as a complex system and internal processes as adaptive cycles and moving away from the implementation of strategic territorial planning.

\section{Sustainability and Resilience in Smart Cities Planning}

\subsection{Temporary Study of Urban Planning (UP)}

In some countries the delimitation of the territory consists of dividing by states or departments, cities, provinces, municipalities, and veredas (rural settlements). The municipalities are understood as a fundamental territorial unit of the political-administrative organization of the state, where the population inhabits and makes up the territories, giving the responsibility of urban planning for reconciling economic growth, environmental care, and social equity [48].

In Colombia, there is the case of the municipal development plan (MDP), which is defined as the navigation chart in pursuit of objectives in favor of improving the quality of life of its beneficiaries, whereas the territorial planning program (TPP) is a tool for the spatial expression of the development policies to be pursued. That is, it delimits land uses and occupations of space according to the aptitudes and ecological and social limits, minimizing the conflicts of the use of the territory, as well as the environmental impacts $[49,50]$.

In this important process, it is essential to visualize the territory in a comprehensive manner, as a consonant link between urban and rural areas [51], allowing for an assertive proposal of the design of strategies that guide the growth and potential of the region that enables the acceptance and articulation between the political and governance levels $[52,53]$. Consequently, cities become a common, dynamic space with the obligation to adapt to common needs that lead to continuous evolution [54], allowing the progressive incorporation of sustainability and resilience as a function of the optimization of the smart cities approach to be identified as a new horizon.

Therefore, the conceptual evolution and perception from its origins to the present goes through four phases: natural planning, empirical planning, functional planning, and modern planning.

\subsubsection{Natural Urban Planning}

Leaving behind their nomadic nature, human beings began their sedentary lifestyle by forming cities and building spaces for their group activities, where the basic organizing element was centered on water sources. That is, if there was a water well within the area to be built, the growth of the settlement was distributed centrally, but if it was a river, it extended parallel to its shore [54,55].

A clear example of the first sedentary groups occurred in Uruk (Mesopotamia, 4500 B.C.), where temples of a length of 68 meters were built, presenting the first ceremonial centers generating a structure of political and religious control, setting the beginnings and later development of agriculture and livestock activities that characterized themselves as the first agricultural villages [56].

\subsubsection{Empirical Urban Planning}

Over time, man began to accumulate experiences in the construction of cities, generating the first environmental impacts. By rethinking the spaces that gave particular characteristics and that supplied the specific needs of the human population, land ended up being categorized; it could be thought that it was the beginning of the figure of land uses [54]. 
Following the example given above, for the period between 2500 and 1700 A.D. in lower Mesopotamia, a stratified society arose with armies and an increasingly complex institutionalized religion. A greater effort was demanded from the worker in order to feed the growing population and meet the demands of the high elites monopolizing urban and agricultural tasks. The overexploitation of soil resources was such that the first salinization occurred as a result of intensified agriculture, producing the irreversible decline of agriculture by 900 B.C., and as a consequence, generating the first forced displacements $[56,57]$.

In the Middle Ages (476 to 1492 A.D.), the basis of the economy continued to depend on agriculture and the clergy, the latter becoming an administrative authority of the empire in power in the main towns, giving way to feudalism and later becoming centers of interregional trade. However, this era was characterized by the displacement of the urban population to the countryside, dispersing it even more as a result of the change in the base of political power [58,59].

In the interest of strengthening the cities, they offered not only security and work, but also freedom from the injustices of the countryside, creating a new category of common people who not only worked as intermediaries or traders, but also provided a series of strictly urban services that made up a city, such as plumbing and carpentry, among others $[58,60]$.

In the modern era between 1493 and 1789, the Catholic kings promoted ordinance policies, even leaving aside medieval privileges, which mainly sought the protection of public spaces and classification of land use for agricultural and livestock exploitation and irrigation districts. In turn, the beautification of the city took on special importance, promoting large construction projects $[60,61]$.

Thus, a connection was beginning to be woven between the phenomena of urbanization, social stratification, demand for natural resources, and ecological degradation for territorial planning.

\subsubsection{Functional Urban Planning}

The arrival of the Industrial Revolution was the impetus for change in agriculture, transport, communication, economy, and society, as well as in territorial planning from a purely utilitarian perspective. At this moment, the concept of functionalism was born, leaving empiricism aside and visualizing territorial planning as an integrated whole that should function effectively for the benefit of the territory's economic bases.

From 1902 to 1930, the constant in cities was the precariousness of public services; therefore, even urban expansion continued occurring around water sources as in its natural stage. In addition to this, household building made a strong entry to supply the high offer from traditional families, creating in general terms the first formalizations of land uses from basic norms supported by instruments to grant construction licenses [62].

Between 1931 and 1960, the need to widen the roads was proposed in order to distribute traffic less homogeneously, emphasizing the differences between streets with dominant vehicle or pedestrian use. There was a concern for the provision of equipment such as schools, hospitals, more modest housing, and parks on a local scale with some meadow. Said influence was adopted from the foundation of the organization International Congresses of Modern Architecture (Congrès Internationaux d'Architecture Moderne-CIAM), which tried to stand out from the traditional urbanism of the time. However, the access to these benefits was defined initially to satisfy the high-income sectors, giving special importance to professionals in the areas of engineering and architecture [62-64].

Although by this time a legal framework was created to regulate the physical expansion of the city, which was already disorderly, this policy still did not involve a citizen participation approach. By the early 1960s, the levels of regional and urban politicaladministrative division were evident, making poverty belts more noticeable by categorizing areas as good or bad $[62,65]$. 
It is not surprising that at this point this approach did not yet build a real plan of the city it desired to reach. It emphasized setting guidelines to guide the daily actions of the city, that is, the city was planned based on immediacy.

\subsubsection{Modern Urban Planning}

At the beginning of the 1970s, the economic growth registered in the industrialized countries as a result of the post-war period produced the industrial reconversion to mass production, mainly for the war industry. At the same time, in another part of the world they faced acute food crises, serious deterioration of agricultural systems, and population growth, with a common denominator: the depletion of resources and the excessive increase in population and per capita consumption [66].

In 1972, the United Nations (UN) at the Stockholm Earth Summit laid the foundations for interaction between the environment and socio-economic aspects, which allowed for influence in the change of economic growth. It was clear that the externalities produced resulted in unwanted consequences in environmental degradation processes, a fact that was increasingly evident in the deterioration of air, water, soil, and biodiversity quality. At this stage, there was a rise of legal instruments for environmental monitoring called "end-of-pipe" or "end-of-stack", so called because they sought to control pollution at the end of the process by allowing, for example, the treatment of contaminant liquid effluents and gaseous emissions. In spite of this, they did not contribute to the prevention of environmental damage nor did they change the nature of the productive processes towards cleaner and more efficient ones, in terms of the use of material and energy resources [67].

However, in order to make the responsibility of the human being in environmental deterioration more evident, the idea of sustainable development was born in 1980 during the declaration of the World Conservation Strategy elaborated by the International Union for the Conservation of Nature (IUCN), with the advice and financial support of the World Wildlife Fund (WWF) and the United Nations Environment Program (UNEP), based on three main objectives: to maintain essential ecological processes and vital systems, to preserve genetic diversity, and to ensure the sustainable use of species and ecosystems [68]. Years later, this opened the way to the European Regional/Spatial Planning Charter from 1983, showing a geographical expression of the economic, social, cultural, and ecological policies of every society (point 8), the balanced development of the territory (point 9), taking into account the human being and their well-being in their interaction with the environment (point 10), and under an interdisciplinary approach (point 9), constituting a prevailing instrument in the evolution of territorial planning [69].

In 1988, the concept of "sustainable development" was coined as one that meets the needs of present generations without compromising the opportunities of future generations to meet their own needs, as stated in the World Commission on the Environment and Development, Brundtland Report [70]. This concept articulates three classic dimensions: environmental, economic, and social, which must be economically livable, economically viable, and socially equitable [71].

Later at the Rio Summit, during the UN Conference on Environment and Development (1992), a world declaration regulating the relationship between environment and development was created. The key subjects of this declaration were framed under the environmental principles of cooperation between states, consumption and overpopulation, environmental control, and participation. The goal of this action plan proposed by the UN was to achieve more sustainable development in the 21st century. The document was approved and signed by 173 heads of state, calling on local governments to assume the commitment to implement the agreements contained in this initiative from their context [72]. Figure 3 shows the evolution of the perspective of UP from a natural vision. The result of the lessons learned matured into modern UP, in which they are still proposed under an approach of biophysical analysis without transcending the improvement of the ecosystem understood from biocentrism. 


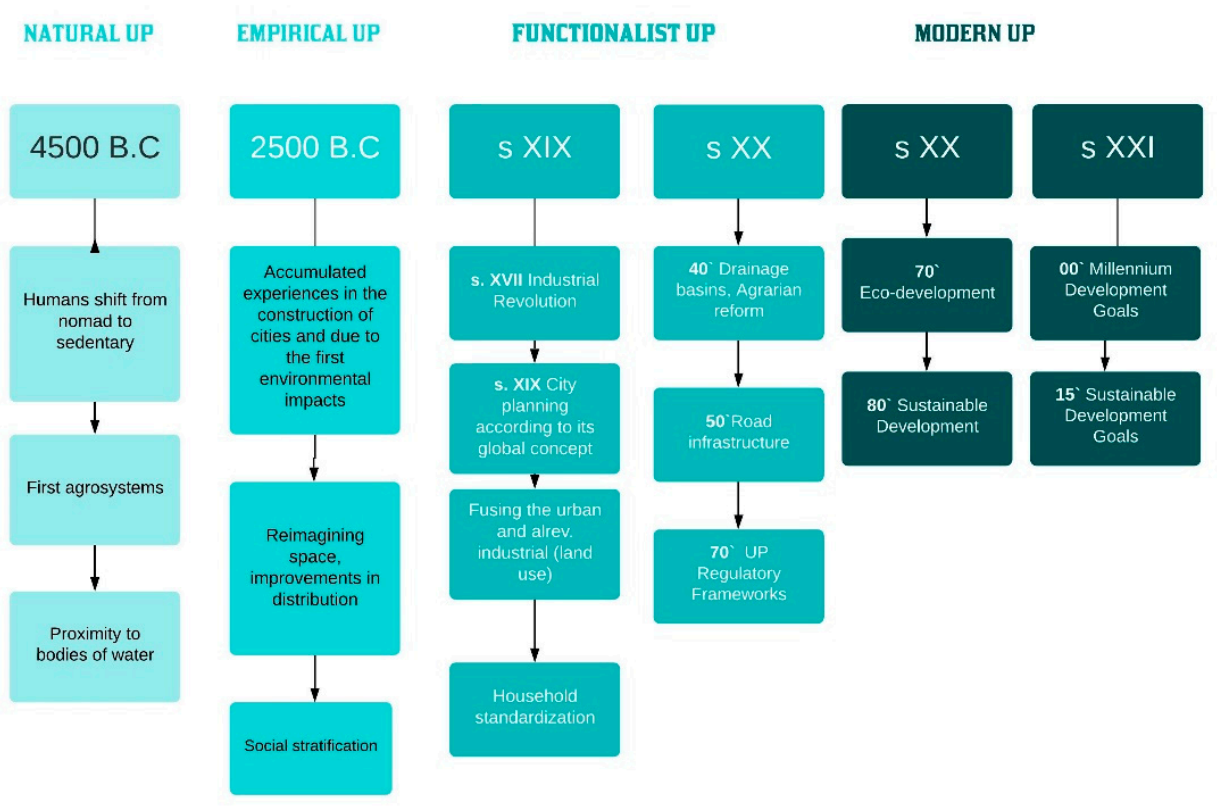

Figure 3. Milestones of urban planning evolution.

\subsection{Approaches to Urban Planning in the 21st Century}

The 21st century began with a constant left by its predecessor: the co-dependence of natural resources, whose poor management resulted in consequences for crucial problems that would frame the new needs of this century-for instance, the occupation and disparity of urban-rural areas, degradation of natural resources and loss of biodiversity, high rates of poverty and marginalization, and vulnerability to natural phenomena [4]. In this context, the outline of a city became even more complex and the approach of traditional urban planning became a limiting factor for strategic urban planning. In 2000, this situation forced a new meeting called the Millennium Conference, during which the member countries signed this agreement before the UN under 8 objectives that had as a goal the year 2015, as shown in Figure 4.

\section{SUSTAINABLE G
DEVELOPMENT GIII:A}
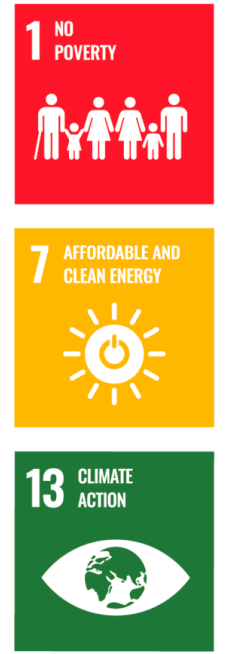
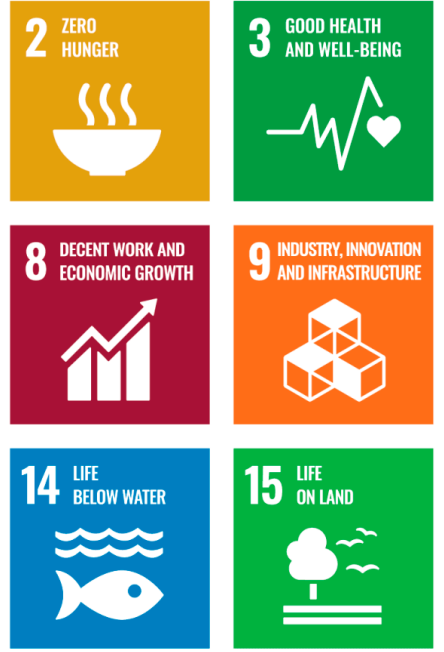
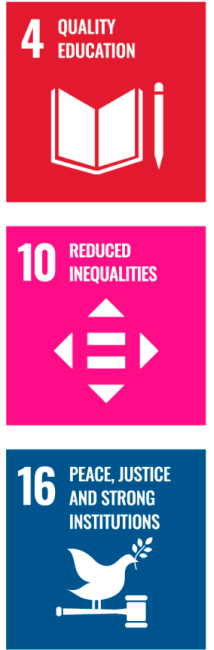
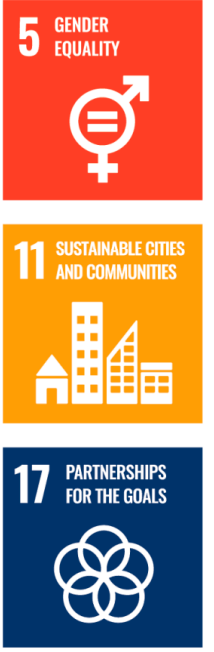
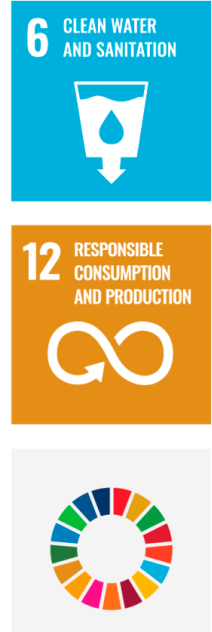

Figure 4. Sustainable Development Goals. 
The above strengthened environmental demands in different parts of the world, calling for responsible consumption and the exaggerated generation of waste and social inequality. In September 2015, the great world representatives approved the 2030 Sustainable Development Agenda, which created 17 Sustainable Development Goals (SDG), as shown in Figure 4, which were universally applicable but not legally binding, in the hope that the different member governments would make them their own in their national policies [73].

In addition to prioritizing poverty reduction, they suggested a pressing and urgent need to place sustainability at the core of public policy design with Goal 11: "Make cities and human settlements inclusive, safe, resilient and sustainable." According to the 2018 UN report related to urban population growth indicators, it was determined that by 2050 at least two-thirds of the world's population would live in cities (Figure 5). This assumption was based on the variation in the percentage of people who moved from rural to urban areas, from $29 \%$ in 1950 to $51 \%$ in 2010; for 2050, this amount is expected to increase to $89 \%$.

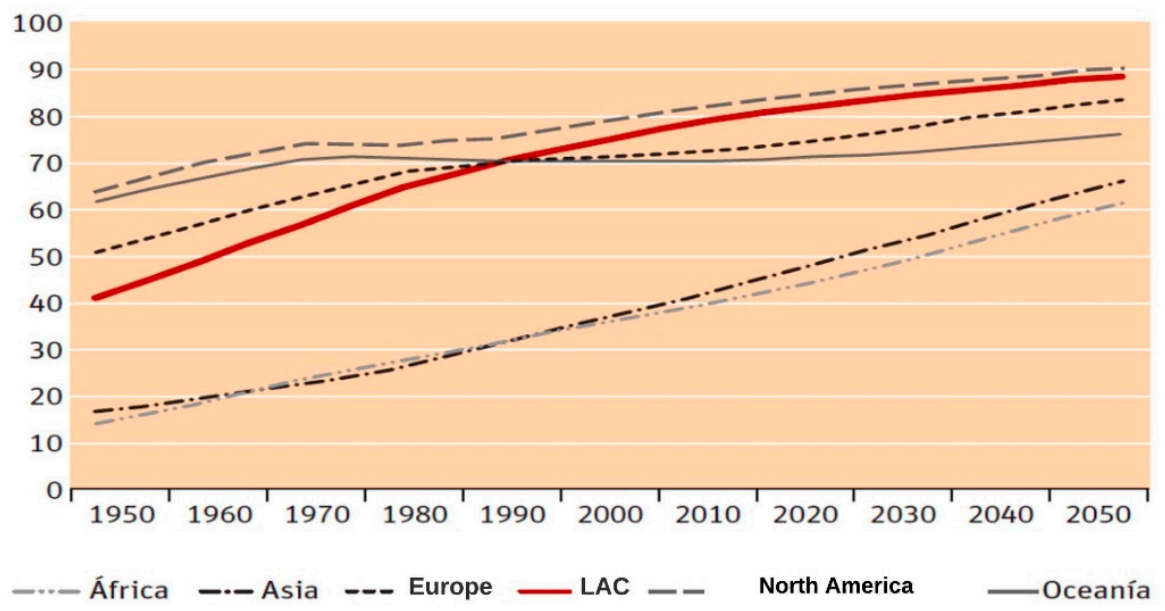

Figure 5. Evolution of urban population by regions.

Throughout this study, there was agreement that the configuration of the territory depended on the transformations given by economic crises and depletion of resources due to inadequate management, leading to economic, social, and environmental collapses, which are repetitive throughout history and in each new version generate a much greater impact that makes it difficult to recover.

First, UP must include the perception of the actors involved in forming a territory; this is known as social cohesion, which focuses on the balanced search for the development of the territory so that its inhabitants can take full advantage of its inherent characteristics through its citizens' sense of belonging with territorial intelligence. UP also aims to make the most of the diversity of factors existing in a region, as well as benefit from the cooperation between territories that guarantees the sustainability of exchanges between them, avoiding that the development of one territory be at the expense of the other and looking to mitigate inequalities or territorial polarization in terms of economy or employment opportunities, among others [71,74].

Given that one of the objectives of UP is to meet the needs of the population and improve its standard of living by increasing employment and reducing poverty, it is necessary to promote endogenous development. To do so, the economic assessment of the territory should incorporate business networks, promoting innovation as part of the evolutionary and strategic process - that is, promoting capital accumulation and economic progress based on local production systems, support for technological change and innovation, and self-sustained development [75].

Urban Planning must also involve a bioregional approach where a territory of water and soils is perceived whose limits are defined by geographical boundaries of ecological systems, which allows essential environmental processes and satisfy territory requirements 
for key species to be sustained, and include human communities in the management, use, and understanding of biological resources [71,76].

These new directions must be accompanied by strategic perspectives for UP, since inherited conflicts become susceptibility factors that are a great threat to guaranteeing the basic needs of the communities and threaten the Sustainable Development Goals.

\subsection{Environmental Sustainability and UP}

Just as urban planning underwent a conceptual and practical evolution marked by key moments in history, so did sustainability. The growing concern in the 1970s about global warming and its devastating consequences was expressed at the first world climate conference in Geneva in 1979.

Years later, the Brundtland Report, prepared by different nations in 1987 for the UN, originally called "Our Common Future", confronts the position of current economic development in contrast to environmental sustainability. Given that it exposed the phenomenon of climate change, it recommended that $\mathrm{CO}_{2}$ emissions be reduced by $20 \%$ by the year 2005 [77]. This was demonstrated by the scientific evidence identified by the Intergovernmental Panel on Climate Change (IPCC) in 1988 [78].

Nevertheless, the response to this evidence lasted until 1992, when in Rio de Janeiro, Brazil, the Framework Convention on Climate Change was adopted, in which the member countries committed to attempting to reduce greenhouse gas (GHG) emissions by the year 2000, establishing guidelines and strategies for the sustainable regulation of strategic ecosystems in the world in order to preserve their richness and extension [79].

At this time, the so-called "end-of-pipe" or "end-of-stack" technologies, which allowed the treatment of liquid effluents and polluting gaseous emissions, became more popular. However, the solution proposed to the problem was insufficient because this type of mitigation technology was characterized by solving the problems once they were caused, but did not address the root cause from the generation of the problem; this did not contribute to the prevention of environmental damage nor did it change the nature of the productive processes to others that were cleaner and more efficient in terms of the use of material and energy resources [80].

In addition, it is important to develop individuals who are concerned about the environment, as stated in the 1977 Declaration of Tbilisi in the USSR, where five objectives of environmental moral education were established [81-84]: “Awareness and sensitivity to the environment; Knowledge and understanding; Attitudes of interest; Techniques for identifying environmental challenges and contributing to their solution; and Participation in activities to solve environmental challenges" [71,80].

This declaration promotes comprehensive and proactive training regarding environmental issues. Young university students have awareness, attitude, and interest in caring for the environment; therefore, spaces are required that allow them to discuss and propose alternatives from their area of study to provide solutions to problems that attract their attention.

Later in 2000, the eight Millennium Development Goals were determined, which established a clear commitment to improving the situation of the citizens of the signatory countries before 2015 (Figure 4). Two years later, the Johannesburg Summit sought to reaffirm the previously established commitment to the Millennium Development Goals and, in addition, to manage financial funds for sustainable development projects in third world countries. This opened the door to the UN Conference on Environment and Development Rio+20, where special emphasis was placed on green economy issues, the Sustainable Development Goals and, through the document "The future we want", the Rio 1992 purposes were reconsidered [84-86].

Such was the empathy with the environment in this awakening of green consciousness that the concept of carrying capacity, understood as "the limit to which the population can extend, which can be supported indefinitely by a given ecosystem, maintaining its productivity, adaptability and capacity for renewal" [85], was deepened in academia, 
making urgent the implementation of environmental footprint assessment models that allowed a quantitative value to be given to the services provided by the environment for living beings that allow them to improve their quality of life related to environmental services. These services, adopted in the 2011-2020 Strategic Plan for Biological Diversity and the Aichi Goals, are defined in the 2005 UN "Millennium Ecosystem Assessment" [78]. Figure 6 presents the Millennium Development Goals.
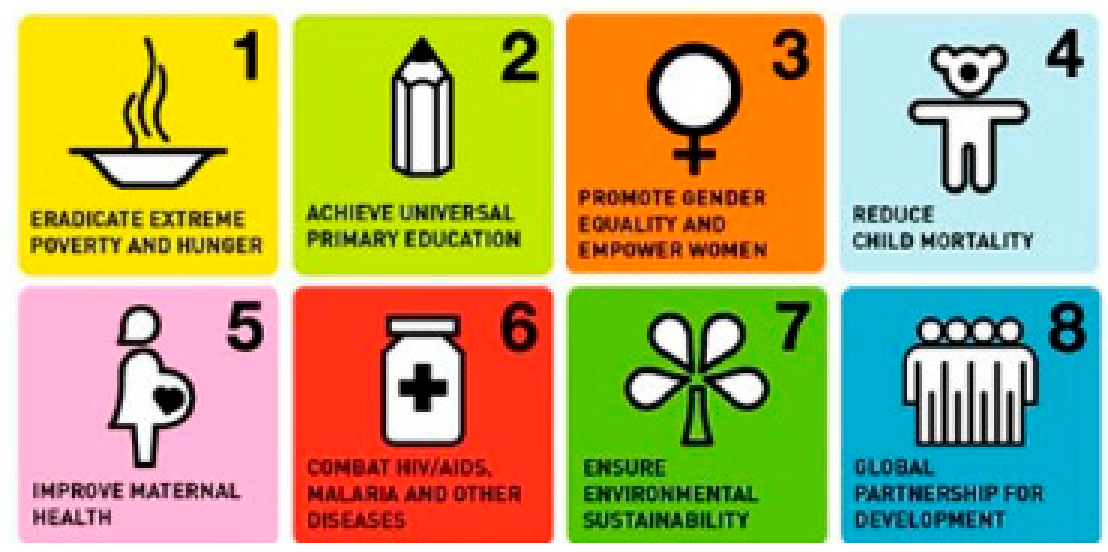

Figure 6. Millennium Development Goals.

In 2015, it was necessary to adopt new, more drastic measures to ensure compliance with the sustainable development approach, so the SDG Agenda 2030 was launched. Also known as the Global Goals, they were a universal call to action to end poverty, protect the planet, and ensure that all people enjoy peace and prosperity [86].

In the timeline shown in Figure 7, it is evident that there were countless efforts of different global organizations to make more evident what was already impossible to hidethat we are a large number of inhabitants on a planet that is becoming more limited to meet our demands.

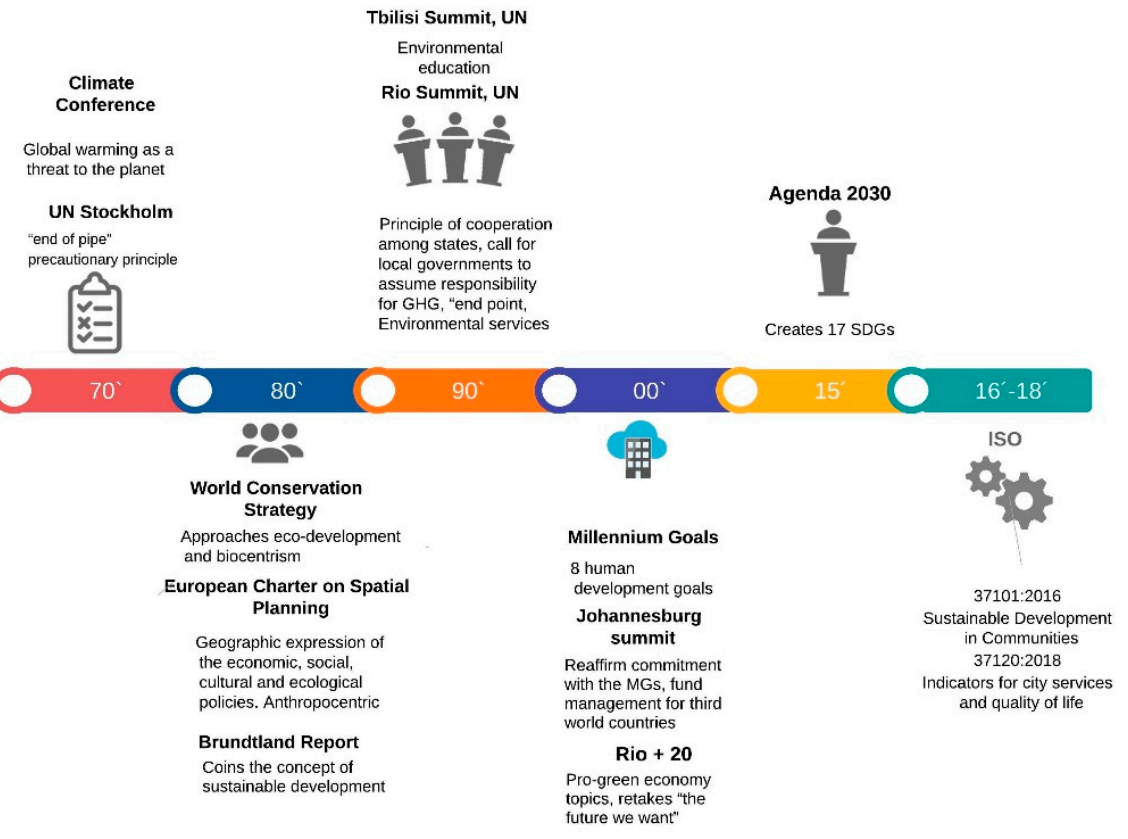

Figure 7. Sustainability timeline.

However, to understand the approaches that have been given to the concept of sustainability, it is worth noting that the Brundtland Summit, at the request of the UN, established 
a concept of sustainable development that framed two particular premises, the first being "satisfying the needs of the generations", and the second element being implicit: "present and future generations." The idea of time is introduced: the temporal variable as a fundamental element of the concept of sustainability, which explicitly shows us that the model of development must be considered in the short, medium, and long term [86-88].

It is important to clarify the difference between sustainable development and sustainability: Sustainability could be called the goal to be achieved, the ideal state to be reached, whereas sustainable development is the path we must travel from the three dimensions: social, environmental, and economic, as presented in Figure 8.

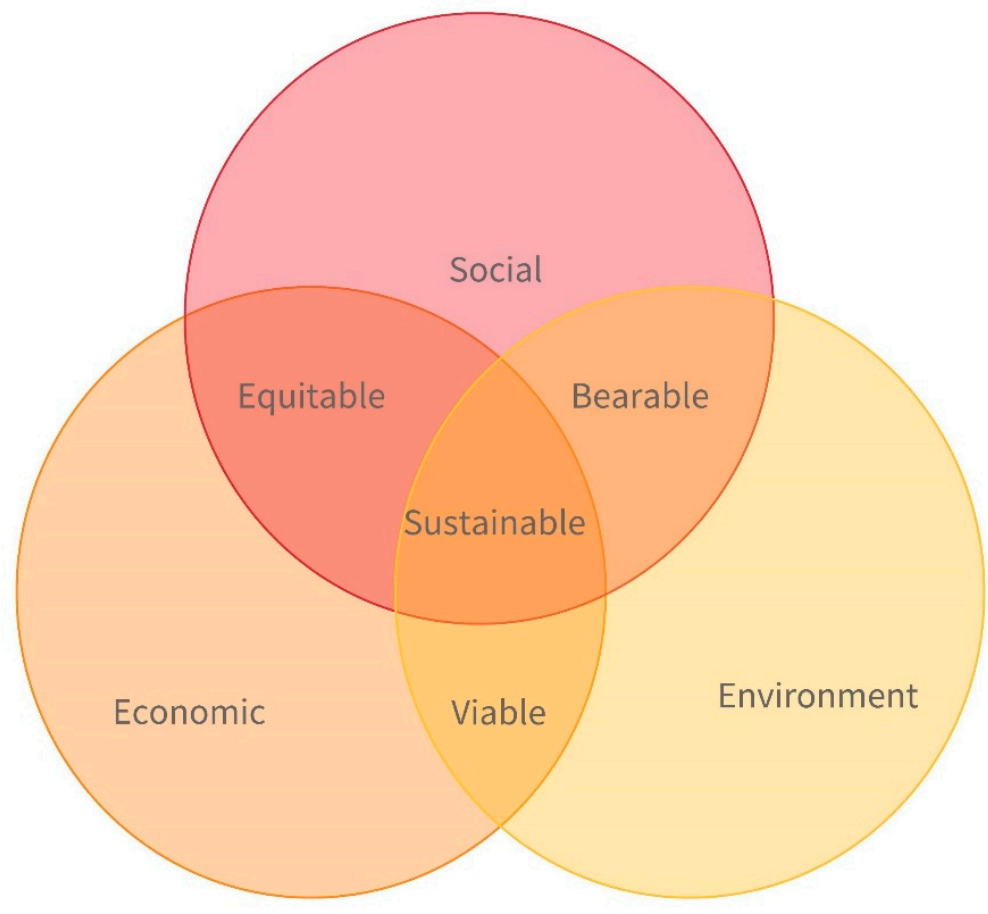

Figure 8. Venn diagram of sustainable development.

The approach of sustainable development is difficult to engage and even more complicated is fulfilling its two premises. This is how the model of "green economy" or "sustainable economy" is reborn. The UN Program called UNEP launched the "Green Economy Initiative" (GEI) in 2008, where the following clarification is made: The concept of green economy is not a substitute for sustainable development, but there is growing recognition of it as "one that leads to improved human welfare and social equity, while significantly reducing environmental risks and ecological scarcity" [85].

Sustainability is a concept that we could intuitively identify, however, in the ISO 37101:2016 standard called "Sustainable development in communities", created under the precepts of the 2030 Agenda of the Sustainable Development Goals for SDG 11. "Sustainable Cities and Communities" promotes the responsible use of resources and the environment and the improvement of the well-being of citizens, who are the final goal.

The above, supported by the ISO 37120:2018 standard called "Sustainable cities and communities: indicators of urban services and quality of life", provides indicators for services and quality of cities that establish the indicators of quality and well-being of life. Within the general principles of this standard, governance, empowerment, education, health, and mobility are identified, which help to define the objectives and strategies of sustainable development. It is outstanding how it is gradually being associated with the territory. Figure 9 shows how the ISO establishes standards for each of the SDGs. 


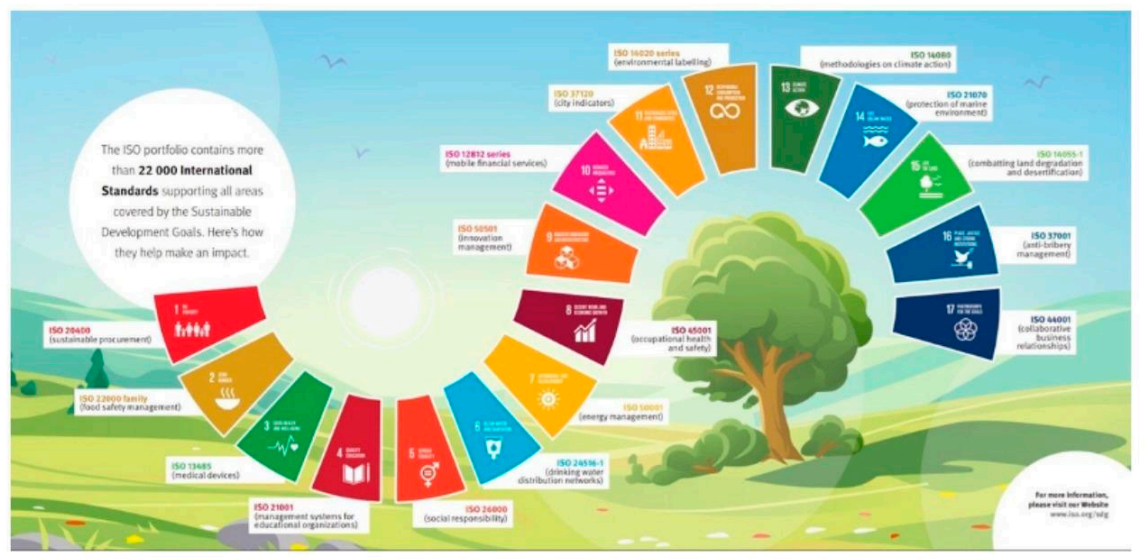

Figure 9. ISO standards for SDGs [22].

\subsection{Resilience in Smart Cities Planning}

As mentioned above, one of the great challenges facing cities is their exponential growth. By 2050, it is estimated that more than $70 \%$ of the population will be concentrated in the main cities, consuming large volumes of natural resources in their path and making their administration even more complex, as well as guaranteeing the minimum quality of life conditions for their inhabitants, forcing decision-makers to seek new alternatives that provide proactive responses to these dilemmas and allowing cities to evaluate, plan, and act in order to prepare for and respond to the new obstacles [37]. This is where the concept of resilience comes into play in urban planning and how it must be adapted to the demands of sustainability.

In 1973, the Ecologist C.S. Holling defined resilience as "a measure of the persistence of systems and their ability to absorb changes and disturbances and maintain the same relationships between populations or state variables", supported by two fundamental variables: stability and regeneration [30]. C.S. Holling's theory had to move from the laboratory as an experimental and analytical model of ecological interactions, to implementation in an ecosystem as a population model. By studying the number of disturbances that a system can maintain before its controls change to another set of variables, Holling evaluated variability, instead of stability.

The first applications of these findings were made at Columbia University in 1978, with the dynamics and management of grasslands and freshwater combining inductive science and field experience, and in 1996 C.S. Holling himself produced ecosystem-scale models [89,90].

By 1998, Simon Levin at Cambridge University considered that the concept ceased to be merely for ecological systems and argued that it was a "property of any complex, nonlinear system, whether ecological or socioeconomic, that does not lend itself to management protocols based on assumptions of linear, globally stable, uniquely balanced systems", evolving into a multidisciplinary concept linked to different uses with very different meanings from the urban perspective [81,91].

Again in 2002, C.S. Holling reappeared, introducing a new vision of resilience from the conception of the "panarchy", where the key element was the interactions between different adaptive cycles; it needed to be seen as an evolutionary nature of complex adaptive systems, where their functioning and sustainability is given by the communication that exists between them, which they trigger in stages of accumulation, restructuring, and renewal, understanding that complex systems seek guidelines, interact with their surroundings, learn from experience, and therefore, transform, turning into adaptations with determinist behavior with positive results after a crisis [81].

By 2005, the consequences of climate change, sea-level rise, and climate extremes led to increased disease, a long list of endangered species, and the destruction of ecosystems, which were difficult to hide. This forced world leaders to meet in the same year in Kobe, 
Hyogo, Japan, at the World Conference on Disaster Reduction, giving special emphasis to risk management and the development of responses through adaptation and mitigation, generating the action framework for 2005-2015 called "Increasing the resilience of nations and communities to natural disasters, leading to a reduction in losses in human lives, social, economic and environmental assets" [11,84].

However, in 2015 together with the SDGs, the UN-Habitat report was published, defining urban resilience as "the capacity of urban systems to recover rapidly from any event caused by disruptive phenomena of natural or human origin. Its purpose is to prevent an event from evolving into a disaster" again under two variables of stability and regeneration. At this point, it was still not very clear whether the disturbances were merely given by factors external to the complex systems or how much influence the internal variables had [37].

As a result of the challenges generated for the fulfillment of the SDGs, the UN guide to urban resilience was created in 2016 for the member countries, which gave special importance to a new concept of risk, which showed the definition of risk from additional variables [37].

The terms "hazard," "exposure," and "vulnerability" are constantly used in risk management, particularly the latter, understood as a characteristic of the community that makes it susceptible to harm from a hazard [71]. Risk assessment involves the analysis of the disruptive agents that can cause damage to a system to the extent that it results in a disaster [84].

For this reason, the guide to resilient cities showed the classification of phenomena to which the territory may be exposed and which significantly affect it, as shown below in Table 1, where each phenomenon is categorized by a type of disturbance that may be of natural, anthropic, or astronomical order, for a total of 37 phenomena.

Table 1. Classification of phenomena [37].

\begin{tabular}{ll}
\hline TYPE & PHENOMENA \\
\hline Geological & 1. Volcanism \\
2. Earthquakes \\
3. Tsunamis \\
4. Instability of slopes \\
5. Flows \\
6. Falls or collapses \\
7. Sinking \\
8. Subsidy \\
\hline 9. Cracking \\
10. Warm and cold waves \\
11. Droughts \\
13. Hailstorms \\
14. Snowstorms \\
15. Tropical cyclones \\
16. Tornadoes \\
17. Dust storms \\
18. Electrical storms \\
19. Extreme rains \\
\end{tabular}


Table 1. Cont.

\begin{tabular}{ll}
\hline TYPE & PHENOMENA \\
\hline Sanitary-ecological & 25. Epidemics \\
& 26. Pests \\
& 27. Air pollution \\
& 28. Water pollution \\
& 29. Soil contamination \\
& 30. Massive movements (marches, pilgrimages) \\
& 31. Large concentrations (sit-ins; political, social, cultural events) \\
& 32. Terrorism \\
33. Sabotage & 34. Vandalism \\
& 35. Air accidents \\
& 36. Maritime accidents \\
& 37. Land accidents \\
\hline
\end{tabular}

Likewise, not only were multiple edges created from which resilience could be interpreted, but also a new approach for governments to respond to their commitments in urban planning by moving towards sustainability commitments, as can be seen in Figure 10, showing its conceptual evolution.

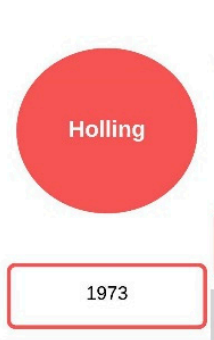

The capacity of the systems to go from one state to the next keeping basic structure and adapting to different perturbations and reorganizing in new configurations

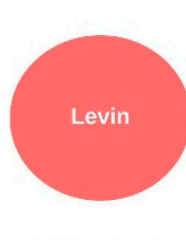

1998

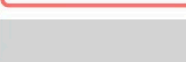

Extends not only to the ecological systems but to any non-linear comple system

Figure 10. Evolution of resilience.

More recently, research focused on finding proactive models that can be implemented to measure a city's resilience. The International Organization for Standardization (ISO) and the UN created the ISO 37123:2018 document "Communities of sustainable development: indicators for resilient cities", where disturbances were defined only as a natural or manmade event that causes a disaster, namely, floods, earthquakes, hurricanes, wildfires, chemical spills, or power outages, which may result in an unstable economy [30].

Currently, multiple organizations of great global influence such as the Resilience Alliance, Community \& Regional Resilience Institute, Resilient City, Network on Building Resilient Regions, or City Resilience Index, play an important role in building and spreading resilience, which, although it is a widely used concept, is rarely well defined [86,92-95]. 
For the City Resilience Index, in the context of cities, "resilience is focused on improving the performance of a system in the face of multiple hazards, rather than preventing or mitigating the loss of assets due to specific events" [25].

\subsection{Smart City Planning Strategies}

At the beginning of the 21st century, the excessive growth of the urban population surpassed the rural population for the first time in 2011, multiplying the number of megacities, which are understood to be those with more than 10 million inhabitants, increasing from three in 1975 to 31 cities by 2016. In this context, the development of smart cities becomes a priority, where technology is put at the service of citizens to manage the urban environment intelligently in order to improve their quality of life [91].

The concept of the digital city, which was born in the 90 s as its precursor, was related to the massive use of information and communication technology (ICT), taking advantage of the existing infrastructure with the domain of the Internet, and providing governmental, private, and civil entities with a set of information-type services that allowed them to break down barriers to share data from one end of the world to the other, and the first steps were taken for the use of computers as an aid to understanding cities [93].

By the end of the 1990s, it was evident that the new challenge was not to collect routine data but rather to make it operable for the benefit of the community and the city, so it became necessary to create technology centers to optimize planning, taking on a role as universal machines [94].

With the arrival of the 21st century, the concept was updated to smart cities based on three fundamental pillars: instrumentation, interconnection, and intelligence in data processing [95]. The first one refers to the need for strengthening the instruments capable of collecting maximum information, the second pillar implies that the maximum traffic of all information may be sustained and that these data can be transmitted to information centers, and the last and most important pillar is not only about collecting and transmitting data but also how it will be processed and analyzed [86].

In response to these needs, it was necessary to integrate the infrastructure associated with ICT with the policies of government agencies in order to contribute to sustainability issues that were mainly focused on energy efficiency and the reduction of greenhouse gas emissions (GHG) [96]. In this manner, it was particularly important to create open data platforms that would allow for citizen participation [97].

Nevertheless, the concept lacks precise definitions and is used with different synonymssmart, creative, digital, connected, cultural - all of them essentially empty since they require definitions that supplement them [40]. Researchers agree that a smart city contains the following six dimensions, as shown in Figure 11.

- Smart economy: Cities must have a high level of productivity, supported by innovation and flexibility in the labor market characterized by innovative solutions and flexible adaptation to changing conditions. The concept of smart industries, linked to information and communication technology (ICT), as well as business parks and technology parks, is applied [98].

- Smart mobility: The infrastructure that supports ICT allows a city to have highspeed connection networks, uniting all the resources, thus letting the use of existing infrastructure to be rationalized [40].

- Smart environment: Energy consumption is optimized, using renewable energy sources and reducing harmful emissions to ecosystems. It is based on the concept of sustainable development [40].

- Smart people: This establishes a society that is open to continuous learning promoted by its inhabitants who, with the appropriate technical support, undertake actions that prevent excessive energy consumption and environmental pollution, contributing to the improvement of the quality of life [40].

- Smart living: This guarantees access to public services, technical and social infrastructure, security, cultural and leisure offerings, and green spaces [40]. 
- Smart governance: This entails optimal management and administration of the territory through a shared management between government agencies, private entities, and citizens, taking advantage of technologies in the operation of the city, an intelligent public administration, capacity to create knowledge, and its use in practice [99].

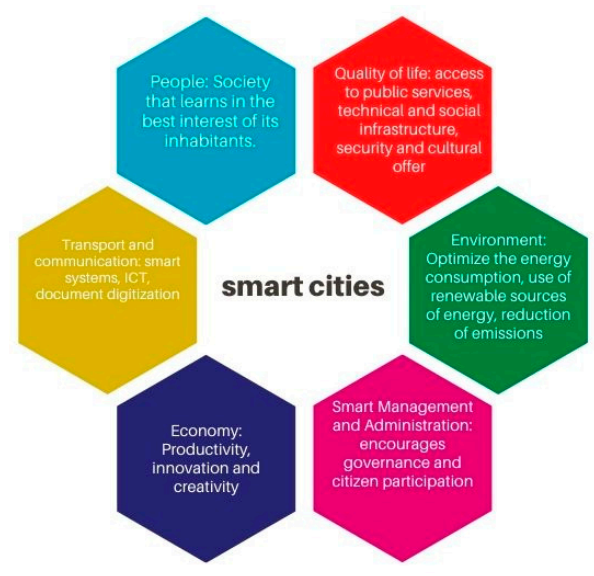

Figure 11. Dimensions of smart cities [40].

These six dimensions are based on the theory of competitiveness of cities and regions, taking the use of technologies as a differentiating element, and covering urban life and the functioning of public administration. Thus, an intelligent city is a territory with the capacity for learning and innovation and creativity, with the presence of institutions dedicated to research and development, higher education, digital infrastructure, and communication technologies, as well as high performance in management and administration [41].

From this new dimensioning, indexes and indicators emerge with the purpose of developing maturity models that allow for the monitoring and integration of operational conditions of a complex system, which uses ICT to innovate in administrative management. Among the existing models is the ISO 37122 standard for smart cities, being a starting point to relate the main characteristics of the perspective of the main domains of a smart city [100-102].

Therefore, one of the objectives that consists of the universalization of services for the development of smart cities is based on the "construction enabled by emerging technologies such as the Internet of Things-IoT and machine-to-machine (M2M), social media, mobility and big data" [102,103]. The development of IoT allows the control of various processes of daily life to be sped up and streamlined, such as the control of areas of transport, health, energy, logistics, the environment, and others [48].

On the other hand, it also becomes relevant to open public data, which allows processing by citizens and requires constant renewal based on the data already obtained. This concept is ideal for an open government that considers maintaining credibility in its citizens and exercising good governance [41].

Environmental planning is an instrument that allows decision-making based on the concepts of resilience and sustainability according to evaluation indicators that allow for strategic direction to face environmental challenges.

As the concept of resilience deepens, it is clear that it allows us to take the first step in adapting to phenomena that may lead to a transformation in the urban ecosystem. However, to improve the performance of the system in the face of these multiple hazards, the need for cooperative work with the smart city approach becomes more evident. This is because the good use of new technologies and communication will allow for the optimization of the quality of life that is offered to citizens. 


\section{Discussion}

\subsection{Planning}

As has been stated throughout the document, planning is as old as man's presence on earth. That is, it is almost in human beings' DNA and was evidenced with, through common sense, the need to reorganize its territory for the common good. With the passing of time, this became a discipline of knowledge and political instruments as a mechanism in favor of an economic system.

It is evident that urban planning has an exponential dependence on existing natural resources, especially water resources, because the guarantee of the well-being of human settlements is focused on the environmental services that this resource provides [8], coupled with historical urban expansion and socio-economic conditions of territory leading to increased demand for natural resources, with negative impacts on the ecosystem.

On the other hand, the creation of political structures and organizations was important for the initiation of territorial planning instruments such as stratifications, categorization, and land use; the last two gave the guidelines for the emergence of equipment, influencing, in turn, cadastral valuations [3-15]. For this reason, these investments in development were initially exclusive to the elites, highlighting the territorial imbalance, framing the poverty belts, and reinforcing the phenomena of disorderly growth in the peripheries.

Although ecodevelopment aims to revolutionize urban planning, under its vision of sustainable development, to change the view of territory from anthropocentrism to bioregion [20,25], it seems that its implementation is becoming even more complex due to the growing demand of a consumer society, which expects to reach a representative level of development, even at the cost of the evident environmental sacrifice that we carry on our backs and which has been a protagonist in the construction of hasty corrective measures.

It is important to remark that the approach of environmental principles such as cooperation, precaution, prevention, biodiversity, and sustainable development discussed at the Rio Summit in 1992 [31] marked a real legal obligation in the instruments of territorial planning, providing important support for the implementation of public policies aimed at sustainability.

Questions arise such as: What is the difference between ancient cities, that is, B.C. cities to those of today? Today the world is very different from that of the Industrial Revolution, with new economic realities, geopolitical tensions, technological advances, new actors involved, and innovative ways of waging wars that globalization has led us to.

In other words, one of the main causes of transformation in cities is due to population growth. That is, while today we have more than 50 megacities with approximately 10 million inhabitants, in ancient times only seven reached a million. Mesoamerican cities have shown growth patterns very similar to those of today, according to the urban scaling model. That is, as they grow, the community tends to inhabit smaller and more concentrated spaces [102].

On the other hand, for ancient cities the walls and fortifications that could be seen from a distance were synonymous with power and authority, something that is not far away today, where modern skyscrapers equipped with the latest technology reflect the fashion for sustainability [102]. However, it can be said that cities governed with a view to equitable distribution showed greater long-term prosperity and competitiveness compared to those governed in an authoritarian manner [103].

\subsection{Sustainability}

The Brundtland Summit established the concept of sustainable development as "development that meets the needs of the present without compromising the ability of future generations to meet their own needs" [88], identifying two notions, the first framed in the environmental footprint and the second in the carrying capacity by assigning a time variable.

Sustainable development is based on a territorial approach aimed at the bioregion, in which the maintenance of essential ecological processes and life support systems, the preservation of genetics, and the sustainable use of species in accordance with their carrying 
capacity are seen as vitally important [22,27]. In other words, it pursues a biocentric vision where the human being is no longer the center and forces urban planning to reevaluate the ordinance of the territory as an instrument that harmonizes with the dynamics of an ecosystem and allows for the evaluation of its carrying capacity and thus guaranteeing long-term planning.

Thus, the declaration of Tbilisi becomes important, establishing the five objectives of environmental moral education $[33,34]$. These were created because it was useless to establish public policies of a police order in the pursuit of compliance with environmental duties if the community was not educated with a vision of taking roots in their territory.

The Millennium Development Goals allowed the establishment of eight objectives, strengthening environmentalist demands and opening doors so that in the UN Conference on Environment and Development Rio+20, special emphasis was placed on green economy issues [89], strengthening as a determining evaluation tool for sustainability, the measurement of the footprint, and the economic valuation of environmental services, which allow for the establishment of a consumption quantification. However, implementation did not guarantee sustainability, because, in addition to a diagnosis, the Conference did not have a robust legal framework that required corrective measures.

\subsection{Resilience}

Territorial planners relate urban resilience to intra-urban processes that are mainly associated with natural disasters [72], perceiving it as an isolated unit and therefore focusing mainly on internal interactions, without giving importance to the fact that the dynamics of these interactions must also be associated at a macro level, which is the relations with other cities.

This allows us to consider cities with a complex systems approach that functions as a network of relationships composed of their internal components and external networks [88]. This works like a gear-that is, each component of its extension fulfills a function and, to the extent that it harmonizes with this internal and external network, it is magnified with a common objective to make this complex system work effectively. These interactions at the local and regional level allow the city to develop further in a multilevel approach.

Hence, a city is seen as a connective element between inter- and intra-urban processes that allows resilience to be raised as a result of their interactions [30]. In these multi-level interactions, "new properties emerge and characterize the city as a collective entity" [89]. It is clear that relationships are the key factor in understanding resilience, but how can each level be measured? Can an analysis of interactions between them be carried out? This is only possible when the point of interconnection and synchronization is understood.

The concept of "panarchy" is postulated as one of the tools to explain the multilevel synchronization of complex systems, as proposed by Hollings in his most recent speech [82]. Thus, urban resilience could be analyzed in its long-term interactions from its key formation factors (exploitation, conservation, liberation, or reorganization). The analysis of these interactions will allow for the contribution of new tools for concepts such as carrying capacity and the measurement of the environmental footprint.

It is important to emphasize that the adoption of measures aimed at implementing resilience is related to risk management from a natural disaster perspective in order to improve the quality of life of citizens [84]. Nevertheless, it would seem that resilience is a magic formula for reducing the vulnerability to which cities are exposed, without considering that it is a concept that is still under construction and is still in search of its key training factors.

Sustainability and resilience are two concepts that will allow a strategic functionality in urban planning, because whereas the first one prioritizes results, the second one analyzes processes, demonstrating that a partnership between these two concepts will allow for a widening of the focus to anticipate anthropocentric and natural uncertainties. 


\subsection{The Smart Cities}

The complexity of the administration of cities makes it imperative to develop smart cities as a tool through which technology is put at the service of citizens, allowing not only for the collection of data but also for the processing of them for the benefit of government entities under the principle of governance.

The smart city is measured in six dimensions: economy, transportation and communications, environment, community, quality of life, and smart management and administration [40]. For this reason, a smart city is a territory with the capacity to learn using technologies as a differentiating element in the hands of institutions dedicated to research and development to improve the quality of life of the community.

\section{Conclusions}

It is inevitable that the conceptual evolution of each of these topics-urban planning, sustainability, resilience, and smart cities—varies according to the historical moment we are going through, together with political needs; however, the main changes in public policies have been produced as a result of natural disasters that show the vulnerability of human beings as one more population in this ecosystem.

It is important to emphasize that such situations should have been generated to allow the concepts of land use to mature, focusing on a common objective that guarantees the well-being of the ecosystem, leaving aside the perception of land from an anthropocentric concept and, in turn, providing tools that allow us to implement the concept of sustainable development and sustainability.

It could be argued that the diversity concept of each of these topics is due to the multidisciplinary nature that breaks up said terminology, but one of the common points is to evaluate the territory as a complex system explaining these concepts through temporal scales, understanding that they can be present in the long term through adaptive cycles where impacts are assessed in the short term by applying the framework of the panarchy.

Sustainability requires predefined results by generating tools that drive a transformation in society in the long term, understanding it as the goal we want to achieve, whereas sustainable development is the road map to establish, allowing for the proactive adaptation and reorganization of public institutions and policies.

It is clear that there is still a long way to go to achieve a practical instrumentalization that addresses and groups all the environmental, social, and economic variables for the optimal administration of the territory, and in addition prepares it for the new challenges.

It is also important to highlight the importance of citizen participation in the creation of territory, which involves identifying and involving groups that may be positively and negatively affected by the transformations in the territory, allowing for free expression and giving importance to debates and cooperation, in turn awakening the understanding of the territory as a bioregion and facilitating citizen participation in the search for compliance with governance.

Compliance with the Sustainable Development Goals is not possible if many obstacles have to be faced in the conservation of physical, chemical, and biological components of the ecosystems. The achievement of sustainable urban development depends on the quality of the environment providing ecosystemic services. Nevertheless, the symbiosis of technology and planning provides a certain path to innovation in intelligent environmental planning, resulting in synergy in favor of the effectiveness of complex systems in the face of latent risks.

We urge the academic community to deepen scientific research that considers naturebased solutions as a pillar for the understanding of adaptive cycles in complex ecosystems such as cities in order to strengthen resilience in risk management and thus improve public policies that will lead to the fulfilment of the Sustainable Development Goals.

Author Contributions: Conceptualization, L.J.R.L. and A.I.G.C.; methodology, L.J.R.L. and A.I.G.C.; software, L.J.R.L. and A.I.G.C.; validation, L.J.R.L. and A.I.G.C.; formal analysis, L.J.R.L. and A.I.G.C.; 
investigation, L.J.R.L. and A.I.G.C.; resources, L.J.R.L. and A.I.G.C.; data curation, L.J.R.L. and A.I.G.C.; writing-original draft preparation, L.J.R.L. and A.I.G.C.; writing-review and editing, L.J.R.L. and A.I.G.C. All authors have read and agreed to the published version of the manuscript.

Funding: This research received no external funding

Acknowledgments: The authors want to thank the Universidad Militar Nueva Granada for the availability of databases in the Doctorate of Applied Sciences.

Conflicts of Interest: The authors declare no conflict of interest.

\section{References}

1. Germán, A. Planeación y Desarrollo, 1st ed.; Book Alfaomega: Madrid, Spain, 2020.

2. Mejía, R.C.; Camacho, C.J. Lineamientos para la Inserción de Restricciones Ambientales en el Ordenamiento Territorial de la Periferia de Maracaibo. I Jornada de Investigación; la Competitividad Institucional en el Siglo XXI. 2020. Available online: https://www.academia.edu/12678148/Lineamientos_para_la_inserci\%C3\%B3n_de_restricciones_ambientales_en_el_ ordenamiento_territorial_de_la_periferia_de_Maracaibo (accessed on 23 July 2020).

3. Hernández-Moreno, S.; Hernández-Moreno, J.A.; Alcaraz-Vargas, B.G. Planeación de bajo carbono de megalópolis en México. Bitácora Urbano Territorial 2019, 29, 49-58. [CrossRef]

4. García, H.; del Mar, M. Las ciudades como objetivo de desarrollo sostenible. BIE3 Boletín IEEE 2017, 5, $22-32$.

5. Bento, S.C.; de Melo Conti, D.; Baptista, R.M.; Ghobril, C.N. As novas diretrizes e a importância do planejamento urbano para o desenvolvimento de cidades sustentáveis. Rev. Gest. Ambient. Sustentabilidade 2018, 7, 469-488. [CrossRef]

6. Kayakutlu, G.; Daim, T.; Kunt, M.; Altay, A.; Suharto, Y. Scenarios for regional waste management. Renew. Sustain. Energy Rev. 2017, 74, 1323-1335. [CrossRef]

7. Ruiz, P.A.C.; Torné, J.M.L. Repensando la ciudad: Estrategias de desarrollo urbano sostenible de las ciudades intermedias de América Latina. Nodo Arquit. Ciudad Medio Ambiente 2015, 10, 73-83.

8. Márquez, J.M.M.; López, A.L. Ciudades sostenibles: Análisis y posibles estrategias. Urbanismo Organización Territorio Clave Multidisciplinar 2015, 17, 59-68.

9. Mercado, G.; Álvarez, L.; Bocaccini, L.; Ledda, M.; Membrives, J.; Muros, M.; López, L.; Juárez, D.; Guillén, L.; Gómez, F.; et al. Diagnóstico y metodología para la implementación de "internet of things" en el planeamiento y desarrollo de ciudades inteligentes. In Proceedings of the IX Workshop de Investigadores en Ciencias de la Computación WICC 2017, ITBA, Buenos Aires, Argentina, 27-28 April 2017; pp. 171-175.

10. Coutinho, S.M.V.; Abilio, C.C.C.; da Penha Vasconcellos, M.; Netto, C.A.A. Indicadores para cidades inteligentes: A emergência de um novo cliché. Revista Gestão Ambiental Sustentabilidade 2019, 8, 389-405. [CrossRef]

11. Nieto, K.R.T.; Potes, L.R. Hábitat sostenible: Adaptación y mitigación frente al cambio climático. Hacia los territorios resilientes. Módulo Arquitectura CUC 2018, 21, 63-96. [CrossRef]

12. Rueda-Palenzuela, S. El urbanismo ecosistémicos. Ciudad Territorio Estudios Territoriales (CyTET) 2020, 51, 723-752.

13. Brouwer, M.T.; van Velzen, E.U.T.; Augustinus, A.; Soethoudt, H.; De Meester, S.; Ragaert, K. Predictive model for the Dutch post-consumer plastic packaging recycling system and implications for the circular economy. Waste Manag. 2018, 71, 62-85. [CrossRef]

14. Pandit, A.; Minn, E.A.; Li, F.; Brown, H.; Jeong, H.; James, J.C.; Newell, J.P.; Weissburg, M.; Chang, M.E.; Xu, M.; et al. Infrastructure ecology: An evolving paradigm for sustainable urban development. J. Clean. Prod. 2017, 163, S19-S27. [CrossRef]

15. Li, F.; Liu, H.; Huisingh, D.; Wang, Y.; Wang, R. Shifting to healthier cities with improved urban ecological infrastructure: From the perspectives of planning, implementation, governance and engineering. J. Clean. Prod. 2017, 163, S1-S11. [CrossRef]

16. Igarza, L.M.Z.; Guisado, R.O.; Campdesuñer, R.P.; González, L.G.C. Perspectivas sostenibles del desarrollo: Integración de la resiliencia a la ordenación urbana. Avances 2019, 21, 394-404.

17. Alcántara, B.; Esther, F. Herramientas y Criterios para una Ciudad Sostenible. Master's Thesis, Universitat Politècnica de Catalunya, Barcelona, Spain, 15 May 2018.

18. Angeoletto, F.; Fellowes, M.D.; Essi, L.; Santos, J.W.; Johann, J.M.; da Silva Leandro, D.; Mendonca, N.M. Ecología urbana y planificación: Una convergéncia ineludible. Revista Electrónica Gestão, Educação Tecnologia Ambiental 2019, 23, 1. [CrossRef]

19. Jaramillo, J.J.S. Acciones de Adaptación y Mitigación al Cambio Climático en La Planificación de La Ciudad de Medellín: De La Sostenibilidad a La Resiliencia Urbana; Universidad Nacional a Distancia: Boyacá, Colombia, 2015.

20. Castiblanco-Prieto, J.J.; Aguilera-Martínez, F.A.; Sarmiento-Valdés, F.A. Principios, criterios y propósitos de desarrollo sustentable para la redensificación en contextos urbanos informales. Revista Arquitectura 2019, 21, 21-33. [CrossRef]

21. Gorgolas, P. Estrategias de actuación para la promoción de una ecociudad: Una experiencia marroquí. El caso de estudio de la comuna de benslimane. In Regeneración y Planeamiento para Ciudades Sostenibles. Experiencias en América, Marruecos Y España; Departamento de Urbanística y Ordenación del Territorio. Escuela Técnica Superior de Arquitectura de Sevilla: Sevilla, Spain, 2020. 
22. International Organization for Standardization. Sustainable Development in Communities_Management System for Sustainable Development-Requirements with Guidance for Use; ISO 37101; International Organization for Standardization: Geneva, Switzerland, 2016.

23. International Organization for Standardization. Ciudades y Comunidades Sostenibles_Indicadores para Ciudades Resilientes; ISO 37123; International Organization for Standardization: Geneva, Switzerland, 2019.

24. María, A.N.E. Visión compartida con la resiliencia como visión global Ciudades fuertes, flexibles, verdes y humanas. Red Universitaria Urbanismo Arquitectura 2017, 18, 1-25.

25. Suárez Casado, M. De las smart cities a los smart citizens: La ciudadanía frente a la tecnología en la construcción de resiliencia urbana. From smart cities to smart citizens: Citizenry against technology in the construction of urban resilience. URBS Revista Estudios Urbanos Ciencias Sociales 2016, 6, 121.

26. Tumini, I. Acercamiento teórico para la integración de los conceptos de resiliencia en los indicadores de sostenibilidad urbana. Revista Urbanismo 2016, 34. [CrossRef]

27. Resilient Design Institute. Available online: https://www.resilientdesign.org/ (accessed on 22 July 2020).

28. Organización Naciones Unidas. Temas Hábitat III 15-Resiliencia urbana. In Proceedings of the Conferencia de las Organización Naciones Unidas, Quito, Ecuador, 17-20 October 2016.

29. Rogov, M.; Rozenblat, C. Urban resilience discourse analysis: Towards a multi-level approach to cities. Sustainability 2018, 10, 4431. [CrossRef]

30. Davalos, J.; Pérez, A.R. Ciudades sostenibles, inclusivas y resilientes: Gobiernos locales y participación ciudadana en la implementación de las agendas globales para el Desarrollo. INNOVA Res. J. 2017, 2, 116-131. [CrossRef]

31. Guerra, P.M.; Lima, H.D.F.; Ortega, J.C.B. Mitigação de desatres em areas urbanas e construção de cidades resilientes. In Proceedings of the EICTI 2017, Foz do Iguaçu, Brasil, 4-6 October 2017.

32. Botequilha-Leitão, A.; Díaz-Varela, E.R. Performance based planning of complex urban social-ecological systems: The quest for sustainability through the promotion of resilience. Sustain. Cities Soc. 2020, 56, 102089. [CrossRef]

33. Casaus, M.A. Deconstruyendo la resiliencia urbana (Deconstructing urban resilience). OBETS Revista Ciencias Sociales 2018, 13, 229-255. [CrossRef]

34. Lipp, D. Ciudades resilientes. Actas Científicas CIG-79 Semana de la Geografía. 2018, 79, 69-74. Available online: http: / / www.gaea.org.ar/ACTAS2018/ACTAS2018LIPP.pdf (accessed on 22 July 2020).

35. Li, T.; Dong, Y.; Liu, Z. A review of social-ecological system resilience: Mechanism, assessment and management. Sci. Total Environ. 2020, 723, 138113. [CrossRef] [PubMed]

36. International Organization for Standardization. Ciudades y Comunidades Sostenibles_Indicadores Para Ciudades Inteligentes; ISO 37122; International Organization for Standardization: Geneva, Switzerland, 2019.

37. Guia de Resiliencia Urbana; ONU-HABITAT: Mexico City, Mexico, 2016.

38. Alderete, M.V. Qué factores influyen en la construcción de ciudades inteligentes? Un modelo multinivel con datos a nivel ciudades y países. CTS Revista Iberoamericana Ciencia Tecnología Sociedad 2019, 14, 71-89.

39. López, R.A.A. Ciudad inteligente y sostenible: Hacia un modelo de innovación inclusive. PAAKAT Revista Tecnología Sociedad 2018, 7. [CrossRef]

40. Sikora-Fernández, D. Factores de desarrollo de las ciudades inteligentes. Revista Universitaria Geografía 2017, 26, 135-152.

41. de Santana, E.D.S.; de Oliveira Nunes, É.; Santos, L.B. The use of ISO 37122 as standard for assessing the maturity level of a smart city. Int. J. Adv. Eng. Res. Sci. 2018, 5, 309-315. [CrossRef]

42. Acevedo, R.; Miranda-Brand, W. Smart cities and territories from the perspective of technological surveillance. Dimensión Empresarial 2019, 17. [CrossRef]

43. Bustillo Holgado, E.; Rodríguez Bustamante, P. Los sistemas de información geográfica y las ciudades inteligentes. Polígonos Revista Geografía 2015, 27, 257. [CrossRef]

44. Lu, J.W.; Chang, N.B.; Liao, L.; Liao, M.Y. Smart and green urban solid waste collection systems: Advances, challenges, and perspectives. IEEE Syst. J. 2017, 11, 2804-2817. [CrossRef]

45. Fergnani Brion, M.F. Evaluation model for sentient cities. Culturas 2016, 3, 55-87. [CrossRef]

46. García, A.; Ortiz de Urbina Criado, M.; Heredero, C.D.P. Information reuse in smart cities' ecosystems: Reutilización de información en las ciudades inteligentes. Profesional Información 2015, $24,838$.

47. Zona-Ortiz, A.T.; Fajardo-Toro, C.H.; Pirachicán, C.M.A. Propuesta de un marco general para el despliegue de ciudades inteligentes apoyado en el desarrollo de Iot en Colombia. Revista Ibérica Sistemas Tecnologias Informação 2020, $28,894-907$.

48. Méndez, H.; Carla, P. Ordenamiento Territorial en el Municipio Una Guía Metodológica, 1st ed.; FAO Organización de las Naciones Unidas para la Alimentación y la Agricultura: Rome, Italy, 2014.

49. Chiarella Quinhoes, R. Planificación del desarrollo territorial: Algunas precisions. Espacio Desarrollo 2010, 22 , 77-102.

50. Murillo, H.G. Contexto para la Planificación, Gestión del Desarrollo y Ordenamiento Territorial Agropecuario; UPRA, Unidad de Planificación Rural Agropecuaria: Bogotá, Colombia, 2018.

51. Troya, E.; Félix, J. Lloa entre lo Urbano y lo Rural: Imaginarios, Territorio y Desarrollo en la Ruralidad. Bachelor's Thesis, Pontificia Universidad Catolica del Ecuador, Quito, Ecuador, 2017.

52. Vasquez, I.M. Los determinantes de ordenamiento territorial como límite a la autonomía local en materia de disposición urbanística del territorio. Revista Digital Derecho Administrativo 2019, 22, 22-25. [CrossRef] 
53. Rea-Padilla, D. Estrategias de Planeación Territorial y Ambiental para Procurar el Equilibrio Sustentable Entre el Desarrollo de la Ciudad y sus Áreas Verdes en el Sur Poniente del AMG. Master's Thesis, Instituto Tecnológico y de Estudios Superiores de Occidente ITESO, Tlaquepaque, Mexico, January 2020.

54. Maria, D. Conceptos Básicos de Urbanismo/Forma y Estructura de la Ciudad/la Administración de la Ciudad/Geografía Urbana, 1st ed.; Trillas Editorial: Chihuahua, Mexico, 2009.

55. Bartram, J.; Corrales, L.; Davison, A.; Deere, D.; Drury, D.; Gordon, B.; Howard, G.; Rinehold, A.; Stevens, M. OMS Manual para el Desarrollo de Planes de Seguridad del Agua: Metodología Pormenorizada de Gestión de Riesgos para Proveedores de Agua de Consumo; World Health Organization: Geneva, Switzerland, 2009.

56. Tur, A. Desigualdad, Urbanismo y Medio Ambiente: La Primera Urbanización; Universidad Católica San Antonio de Murcia: Murcia, Spain, 2002; p. 21.

57. García, J.J.E. Sobre el origen del urbanismo y el modelo de vida urbana en el viejo y nuevo mundo. In Evolución Urbana y Actividad Económica en los Núcleos Históricos; Universidad Católica San Antonio de Murcia: Murcia, Spain, 2002; pp. 7-48.

58. Nicolini, A. La ciudad hispanoamericana, medieval, renacentista y americana. Atrio 2005, 10, 27-36.

59. Vázquez, R. Ordenar la ciudad: Derecho y urbanismo en la Edad Moderna castellana. Anuario Historia Derecho Español 2017, 87, 299-331.

60. Ortman, S.G.; Cabaniss, A.H.F.; Sturm, J.O.; Bettencourt, L.M.A. Settlement scaling and increasing returns in an ancient society. Sci. Adv. 2015, 1, e1400066. [CrossRef]

61. Ames, K. On the evolution of the human capacity for inequality and/or egalitarianism. In Pathways to Power; Springer: Berlin/Heidelberg, Germany, 2010; pp. 15-44.

62. Solano, R.C. Del urbanismo a la planeación en Bogotá (1900-1990) Esquema inicial y materiales para pensar la trama de un relato Del urbanismo a la planeación en Bogotá (1900-1990) Esquema inicial y materiales para pensar la trama de un relato. Bitácora Urbano Territorial 2011, 11, 55.

63. Delgado, J. De los anillos a la segregación. La ciudad de México, 1950-1987. Estudios Demográficos Urbanos 1990, 5, 237-274. [CrossRef]

64. Anonymous. Informe Barlow. Revista Arquitectura. 1970, p. 113. Available online: https://www.coam.org/media/Default\%20 Files/fundacion/biblioteca/revista-arquitectura-100/1959-1973/docs/revista-articulos/revista-arquitectura-1970-n140-pag1 13.pdf (accessed on 20 June 2020).

65. Padua, M.B.; Garcés, C. Contribuciones de la CEPAL en los estudios del fenómeno urbano metropolitano, 1950-1990. Revista Estudios Regionales 2004, 70, 149-172.

66. Jankilevich, S. Las cumbres mundiales sobre el ambiente Estocolmo, Rio y Johannesburgo 30 años de Historia Ambiental; Universidad de Belgrano Area de Estudios Ambientales y Urbanos: Buenos Aires, Argentina, 2012.

67. Agoglia Moreno, B. La Crisis ambiental como proceso. Un análisis reflexivo sobre su emergencia, desarrollo y profundización desde la perspectiva de la teoría crítica. Ph.D. Thesis, Universitat de Girona, Girona, Spain, 2011.

68. Vázquez, F.J.C. Repensando la sostenibilidad: Desarrollo sostenible, migraciones y codesarrollo en un mundo global. DELOS Desarrollo Local Sostenible 2011, 4, 1, ISSN-e 1988-5245.

69. López Ramón, F. Introducción a los significados de la ordenación del territorio en Europa. Revista Administración Pública 2005, $166,213-230$.

70. Informe libro verde de cohesión territorial: Convertir la diversidad territorial en un punto fuerte. In Proceedings of the Comisión de las Comunidades Europeas, Brussels, Belgium, 6 October 2008.

71. Subgerencia Cultural del Banco de la República. Capacidad de Carga de un Ecosistema. 2015. Available online: http://www. banrepcultural.org/blaavirtual/ayudadetareas/ciencias/capacidad_de_carga_de_un_ecosistema (accessed on 23 July 2020).

72. Meléndez, F.C.; Piña, D.I.; Barreto, R.F.S.; Aquino, R.J.C.; Calderón, H.A.; López, F.P. Discusión Epistemológica en Torno a la Sustenibilidad y el Desarrollo; Colofón Ediciones Académicas: Mexico City, Mexico, 2018.

73. Beita, C.M. Ordenamiento territorial: Desafíos para una sociedad en crisis ecológica. GEOUSP: Espaço Tempo 2015, 19, 312-323. [CrossRef]

74. Informe de los Objetivos de Desarrollo Sostenible; Naciones Unidas: New York, NY, USA, 2018.

75. Cuberos, R. Cambios de paradigma en la ordenación del territorio. In Planificación Territorial y Desarrollo Sostenible; Facultad de Arquitectura y Diseño, Universidad del Zulia: Maracaibo, Venezuela, 2017; p. 15.

76. Reguero, B.G.; Beck, M.W.; Losada, I.J.; Narayan, S. Uniendo ingeniería y ecología: La protección costera basada en ecosistemas. Ribagua 2017, 4, 41-58. [CrossRef]

77. Zillman, J.W. Historia de las actividades en torno al clima. In Proceedings of the Tercera Conferencia Mundial sobre el Clima, Geneva, Switzerland, 31 August-4 December 2009.

78. Caselles Moncho, A.; Carrasco Esteve, M.; Martínez Gascón, A.; Coll Ribera, S.; Doménech Quesada, J.L.; González Arenales, M. La Huella Ecológica Corporativa de los Materiales: Aplicación al Sector Commercial; Observatorio Iberoamericano del Desarrollo Local y la Economía Social: Malaga, Spain, 2008.

79. Ribera, T.; Olabe Egaña, A. La cumbre del clima en París. DT 2015, 3, 2015.

80. Agius, E. Ética ambiental: Hacia una perspectiva intergeneracional. In Ética Ambiental y Políticas Internacionales; Organización de las Naciones Unidas para la Educación, la Ciencia y la Cultura: Paris, France, 2010; pp. 89-115.

81. Walker, B. Resilience, instability, and disturbance in ecosystem dynamics. Environ. Dev. Econ. 1998, 3, 221-262. [CrossRef] 
82. Prieto Barboza, E. Resiliencia y panarquía: Claves para enfrentar la adversidad en sistemas sociales. Red Revistas Científicas América Latina Caribe España Portugal 2013, 13, 8.

83. López, Z.R.A.; López, T.R.A. Ética Ambiental: Estudio exploratorio de la percepción estudiantil universitaria. Revista Sci. 2019, 4, 221-238.

84. Rincón-Ruíz, A.; Echeverry-Duque, M.; Piñeros, A.M.; Tapia, C.H.; David, A.; Arias-Arévalo, P.; Zuluaga, P.A. Valoración Integral de la Biodiversidad y los Servicios Ecosistémicos: Aspectos Conceptuales y Metodológicos; Instituto de Investigación de Recursos Biológicos Alexander von Humboldt (IAvH): Bogotá, Colombia, 2014; p. 151.

85. UNEP. Towards a Green Economy: Pathways to Sustainable Development and Poverty Eradication-A Synthesis for Policy Makers. 2011. Available online: www.unep.org/greeneconomy (accessed on 23 July 2020).

86. Suárez Casado, M. De las Smart cities a los Smart citizens. La ciudadanía frente a la tecnología en la construcción de resiliencia urbana. URBS. Revista Estudios Urbanos Ciencias Sociales 2016, 6, 128.

87. Lopera, A.P. Legislación ambiental en colombia: Ayer, hoy y desafíos. Summa Iuris 2019, 7, 97-113. [CrossRef]

88. Veza, J. Sostenibilidad: Preguntas Frecuentes ... y algunas respuestas; Universidad de Las Palmas de Gran Canaria, Catedrático de Tecnologías del Medio Ambiente: Gran Canaria, Spain, 2013.

89. Folke, C. Resilience: The emergence of a perspective for social-ecological systems analyses. Glob. Environ. Chang. 2006, 16, 253-267. [CrossRef]

90. Asprone, D.; Manfredi, G. Linking disaster resilience and urban sustainability: A glocal approach for future cities. Disasters 2015, 39, s96-s111. [CrossRef] [PubMed]

91. Pumain, D. (Ed.) Alternative explanations of hierarchical differentiation in urban systems. In Hierarchy in Natural and Social Sciences, Methods Series; Springer: Dordrecht, The Netherlands, 2006; Volume 3, pp. 169-222.

92. Lanfranchi, G.; Herrero, A.; Jaureguiberry, J. Resiliencia Urbana Diálogos Institucionales; Programa de Ciudades de CIPPEC: Buenos Aires, Argentina, 2016.

93. Siade, I.C. 27F/8.8 La reconstrucción de las Ciudades del Borde Costero de la Región del Bio Bio: "Sustentabilidad y Participación para Ciudades Resilientes"; Centre de Política de Sòl i Valoracions Universidad Autónoma de Baja California: Baja California, Mexico, 2010.

94. Méndez, R. Ciudades y metáforas: Sobre el concepto de resiliencia urbana. Dialnet 2012, 172, $215-232$.

95. Ramírez, R.; Matus, M. Ciudades Inteligentes en Iberoamérica; Ejemplos de Iniciativas desde el Sector Privado, la Sociedad Civil., el Gobierno y la Academia; INFOTEC: Mexico City, Mexico, 2016.

96. Batty, M. The computable city. Int. Plan. Stud. 1997, 2, 155-173. [CrossRef]

97. Sáenz, D. Smart Environments: Las TICs en las ciudades inteligentes. In Informe Breve de Tendencias; Instituto Tecnológico de Informática: Valencia, Spain, 2011.

98. Achaerandio, R.; Bigliani, R.; Gallotti, G.; Maldonado, F.; Curto, J. Análisis de las Ciudades Inteligentes en España; International Data Consulting (IDC): Madrid, Spain, 2012; p. 48.

99. Hollands, R.G. Will the real smart city please stand up? City 2008, 12, 303-320. [CrossRef]

100. Caragliu, A.; Del Bo, C.; Nijkamp, P. Smart Cities in Europe. J. Urban. Technol. 2011, 18, 65-82. [CrossRef]

101. Griffinger, R.; Pichler-Milanović, N. Smart Cities: Ranking of European Medium Cities; Centre of Regional Science, Vienna University of Technology: Vienna, Austria, 2007.

102. Komninos, N. Intelligent Cities; Taylor and Francis: Abingdon, UK, 2013.

103. Clarke, R.J. Business Strategy: IDC Government Insights' Smart City Maturity Model Assessment and Action on the Path to Maturity; International Data Corporation (IDC) Government Insights, Business Strategy: Alexandria, VA, USA, 2013. 